\title{
Ulik behandling ved hjerneslag
}

\author{
Både norske og europeiske retningslinjer for behandling og rehabilitering ved hjerneslag har som mål at \\ slagpasienter behandles likeverdig. Men i Norge har ikke alle pasienter tilgang til en slagenhet, og kvaliteten \\ på de enkelte enheter varierer.
}

Behandlingskjeden ved mistanke om hjerneslag bør starte med en effektiv blålystransport. Kliniske tegn på transitorisk iskemisk atakk (TIA) er å regne som «hjernens ustabile angina». European Stroke Organisation (ESO) regner TIA og hjerneslag som likevektige grunner for akutt hjelp og utredning.

Umiddelbar nevroradiologisk diagnostikk er avgjørende for riktig valg av behandling. Mulighet for akutt intravenøs trombolytisk eller invasiv behandling har ført til at dagens slagenhet ikke lenger kan defineres som en geografisk enhet på en sengepost. Slagenhetens arbeid starter så snart pasienten er innenfor sykehusets dører.

\section{Hva gjør en slagenhet?}

Sengene som utgjør den tradisjonelle slagenheten, med et tverrfaglig team for akuttovervåking og tidlig rehabilitering, er fortsatt kjernen i pasientens stabiliserende behandling. Spesialiserte slagsykepleiere overvåker pasientens nevrologiske og øvrige funksjonsstatus ved hjelp av repeterte standardiserte skåringer (National Institute of Health Stroke Scale, NIHSS), EKG, blodtrykk, temperatur og blodsukker for å oppdage tegn til komplikasjoner og tidlig sette inn korrigerende tiltak.

Bildedannende ultralyd og dopplermålinger er en integrert del av slagenhetens arbeid og bør utføres raskest mulig for å supplere informasjonen fra CT- eller MR-angiografi for kartlegging av aterosklerose og hemodynamikk samt monitorering av embolier. Arbeidet med å finne og behandle årsak til hjerneinfarktet, kartlegge risikofaktorer og avdekke organskader fortsetter i samarbeid med kardiolog, karkirurg, endokrino$\log$, nefrolog, hematolog, øyelege og andre aktuelle spesialister.

Parallelt med videre utredning og behandling av årsaken må rehabiliterende behandling starte. For pasienter som ikke har fått trombolytisk behandling eller intervensjon eller som har hatt utilstrekkelig effekt eller komplikasjoner av akuttbehandlingen, kan rehabilitering bli viktig og langvarig. Slagenhetens tverrfaglige rehabiliteringsteam, primært fysioterapeut, logoped og ergoterapeut, starter vurdering og behandling på slagenheten raskest mulig.

Kvaliteten på akutt slagbehandling avhenger av kunnskap og organisering. God kunnskap om nevrologiske og nevroradiologiske differensialdiagnoser er viktige faktorer for rett diagnose, kvalitet og pasientsikkerhet. Ved svak nevrologisk kompetanse bør det i akuttsituasjonen benyttes «teleslag», som er en direkte samhandling mellom behandlende lege, pasient og nevrolog via videokonferanse. Er «tele-

\section{«Norge har foreløpig ikke ett eneste slag- senter som ville kunne godkjennes etter ESO- anbefalinger»}

slag» ikke etablert, må telefon, eventuelt kombinert med rask elektronisk bildeoverføring, benyttes.

\section{Slagenheter er ulike}

Det finnes tre hovedkategorier av slagenheter i Norge:

- Slagenheter på universitetssykehusnivå, som er en «alt under ett tak»-modell med høy kompetanse på akutte nevrologiske vurderinger, nevroradiologi, nevroradiologisk intervensjon, nevrokirurgi, anestesi og andre aktuelle spesialiteter, overvåking og monitorering ved slagsykepleier og lege samt tverrfaglig rehabilitering.

- Slagenheter der den første akuttmedisinske vurderingen og intravenøs trombolytisk behandling baseres på kombinert kompetanse av slaglege, radiolog og eventuell rådgivende nevrolog via telemedisinsk konsultasjon.

- Sykehusavdelinger uten formalisert slagenhet og med vedvarende lav trombolysefrekvens. Noen få av disse har teleslagtilknytning, men bruker denne i mye mindre grad enn forventet.

\section{Kvaliteten varierer}

Viktige kvalitetsindikatorer i akuttbehandlingen er trombolysefrekvens og tidsbruk fra pasientens ankomst til start av trombolyse eller embolektomi. Også antall pasienter som innlegges med spørsmål om hjerneslag, antall pasienter med bekreftet TIA eller hjerneslag, alder, NIHSS-skår, komorbiditet og antall risikofaktorer etter nasjonalt brukte definisjoner, utført diagnostikk, utført type intervensjon og dokumentert diskusjon av intervensjon med nærmeste universitetsklinikk samt skåringsverktøyet modifisert Rankin-skala (mRS) etter 30 dager må inkluderes i kvalitetsvurderingen for sammenlikning av dagens slagbehandlende sykehusenheter (1).

I de nasjonale faglige retningslinjene for behandling og rehabilitering ved hjerneslag fra 2010 påpekes at det «vil være nødvendig å etablere noen spesialiserte slagsentre i Norge. Disse sentrene bør også fungere som ressursbase med rådgivning og kompetanseoverføring til de øvrige slagenhetene i regionen» (2).

Etter ESO-kriteriene skal et slagsenter ha en høy frekvens av pasienter som innlegges med mistenkt hjerneslag. Et utvidet slagteam bestående av nevrolog, nevroradiologisk intervensjonskompetanse, slagsykepleier, anestesipersonale og nevrokirurg samt CT-, MR- og intervensjonsberedskap, ekstrakraniale og transkraniale ultralydundersøkelser og minst fire overvåkningssenger bør være etablert på 24 timers/sju dagers basis (3). Bare på den måten kan man sikre at pasienter behandles likeverdig på dag- og nattestid, på hverdager og i helgene.

\section{Reorganisering nytter}

ESO-retningslinjene fra 2013 (3) bør være retningsgivende også for Norge. En sertifiseringsordning bør vurderes for å stimulere til økt kvalitet i infrastruktur, diagnostikk og behandling og for å oppnå mer enhetlige behandlingstilbud. Norge har sammen med andre vesteuropeiske land et godt helsetilbud og lavere mortalitet enn øst i Europa (4). Likevel er slagbehandling verken i Norge eller i resten av Vest-Europa enhetlig (3). I London har omorganisering av sykehusenes ansvar for spesialisert behandling av hjerneslag nylig fort til betydelig regional forbedring i slagmedisinen (5). Norge har foreløpig ikke ett eneste slagsenter som ville kunne godkjennes etter ESO-anbefalinger for hjerneslagbehandling i Europa.

\section{Ulrike Waje-Andreassen uwan@helse-bergen.no Lars Thomassen}


Lars Thomassen (f. 1947) er spesialist i nevrologi, overlege ved Senter for nevrovaskulære sykdommer, Nevrologisk avdeling. Haukeland universitetssykehus, professor ved Universitetet i Bergen og tidligere medlem i ESO Stroke Unit Certification Committee.

Forfatter har fylt ut ICMJE-skjemaet og oppgir ingen interessekonflikter.

\section{Litteratur}

1. Katzan IL, Spertus J, Bettger JP et al. Risk adjustment of ischemic stroke outcomes for comparing hospital performance: a statement for healthcare professionals from the American Heart Association/American Stroke Association. Stroke 2014; 45: $918-44$.

2. Nasjonale faglige retningslinjer for behandling og rehabilitering ved hjerneslag.Organisering av spesialiserte slagsentra. Oslo: Helsedirektoratet, 2010.

3. Ringelstein EB, Chamorro A, Kaste M et al. European Stroke Organisation recommendations to establish a stroke unit and stroke center. Stroke 2013; 44: 828-40.

4. Johnston SC, Mendis S, Mathers CD. Global variation in stroke burden and mortality: estimates from monitoring, surveillance, and modelling. Lancet Neurol 2009: 8: 345-54.

5. Stroke Care. www.strokecare.co.uk/ london-stroke-model (14.5.2014)

Mottatt 21.3. 2014, første revisjon innsendt 23.4 2014, godkjent 5.7. 2014. Redaktør: Are Brean.

Publisert først på nett. 